\title{
Key Performance Indicators in Retrofitting Projects: A Review
}

\author{
Hussein A. Khudhair ${ }^{1}$ and Zeynep Isik $^{2}$
}

\begin{abstract}
The biggest challenge of the modern day life is that to make a building resilient to its requirements. The management of energy and improving indoor quality would enhance the work performance and reduce the outlay of government subsidy, and the enhancement of buildings in order to withstand natural disasters and severe ambient conditions would extend the assumable life cycle of the building, this is the essence of the measurement of the level sustainability of a building retrofit projects. The applicability of the key performance indicators (KPIs) as a tool to measure the performance of building retrofitted projects has made it famous among others in the literature. This effort is to underpin the operation of KPI management and measurement by providing an overview of international approaches to KPI measurements in retrofitting projects.
\end{abstract}

Index Terms-KPI, Renovation, Refurbishment, Retrofitting projects.

\section{INTRODUCTION}

A single project may include elements of retrofitting, refurbishment or, renovation, building maintenance is defined by the RICS (1990) as the work undertaken to keep, restore and improve every part of a building. It includes improvement, refurbishment, maintenance, and repair works to the existing private and public constructed facilities [1].

Every building is unique as a result of its proportions, design, function, age, location, and level of resistance to various environmental effects. These properties have a major impact upon the state of the building and accompanying selection of refurbishment actions. An important component in the decision process is also the preliminary condition of the facility $[2,3]$.

Initial condition needs to be assessed by a well-defined, systematic methodology and performed by a trained inspector. Within the assessment process, total energy consumption and structural integrity have to be determined, as well as the condition of individual (structural and non-structural) components of the building, such as windows, facade, chimney, partition walls... Incorporated with clearly specified prerequisites and needs of the owner and/or user, and owners' financial limitations, it represents the basic for further performance evaluation regarding retrofitting. The aim of this

Hussein A. Khudhair is with the Faculty of Construction/Yildiz Technical University, İnşaat Mühendisliği Bölümü Yapı İşletmesi Anabilim dalı Davutpaşa Kampüs Esenler İstanbul, Turkey

Zeynep Isik is with the Faculty of Construction/Yildiz Technical University, İnşaat Mühendisliği Bölümü Yapı İşletmesi Anabilim dalı 1-055 Davutpaşa Kampüs Esenler İstanbul study is to review what had been written on the development of KPI'S for the retrofitted projects and how to develop a framework for the classification of those KPI'S from different perspectives

\section{ClassificAtion Of Performance IndicAtors IN RETROFITTED PROJECTS}

The unique features of a building maintenance in terms of its ability to create economic wealth, deliver social welfare services and at the same time its possibility to create negative environmental impact suggest that this kind of a project needs to be evaluated on economic as well as social and environmental dimensions. However, these projects have mostly been evaluated on the criteria of cost, time and quality, as revealed in the literature [4-7]. This conventional concept, popularly referred to as the "iron triangle". (Atkinson, 1999)[5] Merely catches the economical facets and ignores other pertinent aspects of constructed building projects. Herein drawback of traditional criteria, Organization for Economic Co-operation and Development's (OECD) Development Assistance Committee (DAC) has introduced a performance assessment measure of projects based upon relevancy, efficiency, capability, impact, and sustainability [8-10]. This measure, widely referred to as the five pillars of development projects $[8,10]$, though seems to capture both economic and social facets, do not adequately deal with the environmental elements that are considered quite important in these styles of projects. Further, the researchers have suggested hardly any objective measure upon which the five pillars can be operationalized.

So as to identify suitable criteria whereby various refurbishment scenarios will be judged, advantages gained by various refurbishment actions need to be defined. Three major sorts of benefits could be identified after the refurbishment of a building. The first is the reduced energy consumption is a result of refurbishment that consists of energy rehabilitation of the building and could be efficiently converted into monetary value.

The second benefit appears at the occurrence of a natural disaster, e.g. earthquake. It comes to the effect if the building is appropriately reinforced for the particular natural disaster type at the time of its occurrence. Along with the described direct damage to the building, indirect damage, like the number of days the building is out of use, the cost of temporary relocation of activities being performed in the building to another location, ... etc., can also cause the loss of human lives and that would an ethical [11], The third benefit is associated with the 
increased value (however not market value) of the building due to its renewal and related investment. This value refers to the monetary value of the materials and equipment built in the building only. Each building has, irrespective of its purpose, a certain value in terms of its in-built material and equipment. The increased value (the benefit) is the monetary value of the materials and equipment built into the facility during refurbishment [12].

It is believed that the basic objectives of cost, time and quality should appear on all projects, and major renovation projects are often aided by other considerations such as minimal disruption to the operation of the building and safety of its occupants and users.

This was recalled by Chanter and Swallow (1996), and Headley and Griffith (1997),[12-14] who incorporated both safety and functionality as KPIs for building maintenance projects. Sherwin (2000) further considered environmental friendliness as an important KPI for building renovation projects and suggested modern maintenance management systems should include regulations for safety and environmental lawful criteria [15]. The traditional measurements of project success in the construction industry are namely, schedule (time), cost, performance (quality) and safety [16].

At identifying KPIs for public building retrofitting projects, there exists some consensus among previous researchers on the traditionally accepted indicators for assessing the performance of building maintenance projects and a framework can be developed for the current study and serves as a reference to construction management practitioners to consider.

Over the past thirty years, the value of the management of existing buildings is progressively increasing with time. Retrofitting of buildings requires implementation of various actions that need to be carefully selected, a selection of a set of refurbishment action needs that the goals of contemporaneous sustainable development are achieved. Therefore, a reasonable decision model is called for to select a set of retrofitting measures for a building that produces a largest total benefit to cost ratio. A KPI is the measure of the performance of the process that is critical to its success [17]. Despite the complexities involved in measuring project success, a measurement can be developed based on the subjective perceptions of project participants towards project success.

Allen (1993) indicated that performance indicators could offer a broad perspective in the evaluation of the performance of maintenance projects, including budget per square meter, manpower mix, the age of buildings and occupancy level of hospitalization wards [18].

From the rigorous literature review of previous studies who employed KPI concept to define the performance of building maintenance and from the above-mentioned discussion this study will be classified into five perspectives: project-based measures, quality, societal, functional, and environmental (see Fig.1.).

\section{PROJECT BASED KPIS}

The construction industry is mainly project-based $[19,20]$.
Therefore, this perspective requires construction organizations to drive focus on evaluating the successful achievement of project performance. Project performance is the realization of predefined project objectives [20], and hence project success. The chief basis for adopting project based KPIs for defining the sustainability amount of any construction project arises from the project's requirement for taking up a comprehensive and accurate planning. according to their implicit assumptions concerning the impact of the maintenance system on the business, it will be classified into three levels: financial, time, and safety.

Project management not just enables the cooperation among the diverse stakeholders as well as the functioning teams, but also makes a significant contribution towards other project goals taking in the well-timed high-quality delivery of the project, similarly, maintenance-cost-related measures are deemed important. Dunphy et al, (2012) mentioned the capital investment cost for the possible retrofitting measures in case study in Europe [21], we may see also that mineral resource depletion was put in the financial rather than the environmental category because of its impact on raising of the construction cost indirectly, which makes the need to find new materials to keep the cost at acceptable levels [22], according to Ugwu and Haupt (2007) they developed a set of KPIs categorized direct and indirect costs among which are the life-cycle cost, besides the indirect ones incorporated the rehabilitation of ecosystem and the resettling of people[23]. Dijkstra et al, [22] adopted the net present cost (NPC) which gives the sum of the discounted costs over the period of interest per renovation concept. The NPC was chosen because a renovation is often an investment to reduce the annual costs, on which the retrofitting would be more economically beneficial for a certain amount of time while these are still costs and not benefits [22]. Chan and Chan, [24] explained time of construction is the absolute time that is calculated as the number of days/weeks from start on site to practical completion of the project, it is a crucial factor that affects developers, contractors, and owners, and sometimes general public, time factor was expressed as important KPI by Ngacho and Das, [25] and Yahya et al, [26] both employed 5-point likert scale other extend their studies to the unexpected processes in projects like effect of weather and timely delivery of resources as adopted by Ngacho and Das [25]. Job safety is important since accidents, injuries, fatalities would lead to legal claim and cost burdening besides hindering the project's processes was adopted by Ugwu and Haupt [27], and Yahya et al, [26] adopted the generic name; safety, while Feifer [28], used 'Fire safety', and 'Security against intruders and vandalism' as his occupational safety performance indicators, see table 1 ..

\section{QUALITY}

KPIs Quality control is quite compulsory for every construction project, whether it's for the purpose of time durability, or safety and health reasons. In addition, the significance of taking into account the quality aspect of the measurement of retrofitting projects is considered, as being poor quality during projects might result to several reworks that 
destabilize other projects KPIs. The insertion of quality during the performance assessment of construction ventures has been highlighted through Ngacho and Das [25], Amongst the quality KPIs adopted by Ngacho and Das [25], are 'Right material was used for the construction work, to ensure the customer satisfaction of the project by using the right materials on the standards of the project. While maintenance organizations depend entirely on the performance of employees to achieve their objectives. However, the quality of employees 'work in the maintenance services cannot be measured directly. Knowing the personnel's experience, education, training and skills is essential to measure adequately the result of the work performed an all-encompassing they adopt the 'Workers were trained on positive attitudes' KPI that were evaluated through a five-point Likert scale, varying from one (1) being 'Strongly Disagree' to five (5) being 'Strongly Agree', See table1-2.

\section{SOCIETAL KPIS}

The social problems part of developing renovation ventures were also found as being prevalent amongst the adopted KPIs during past studies. The social KPIs are normally assessed on the basis of the standpoint of the stakeholders directly impacted and affected through the project, the social performance indicator, which was considered through De Wilde and Tian [29], would be adopted for the examination on the thermal outcome of their theoretical office development was 'Office work performance' KPI that was evaluated as well as presented in form of percentage [\%].Soft or perceptual measures like stakeholder satisfaction and employee commitment are often leading indicators in the way that they are highly anticipating of financial performance. Keep track of such measures today generates less concern about tomorrow's budgets [30]. De Wilde and Tian [29], states that there a close relationship between the workers' productivity and their ambient working environment, evolving the office work performance KPI and measured in percentage [\%], The productivity is reduced by $8.9 \%$ when the indoor temperature rises to $30{ }^{\circ} \mathrm{C}$, see table 1-3.

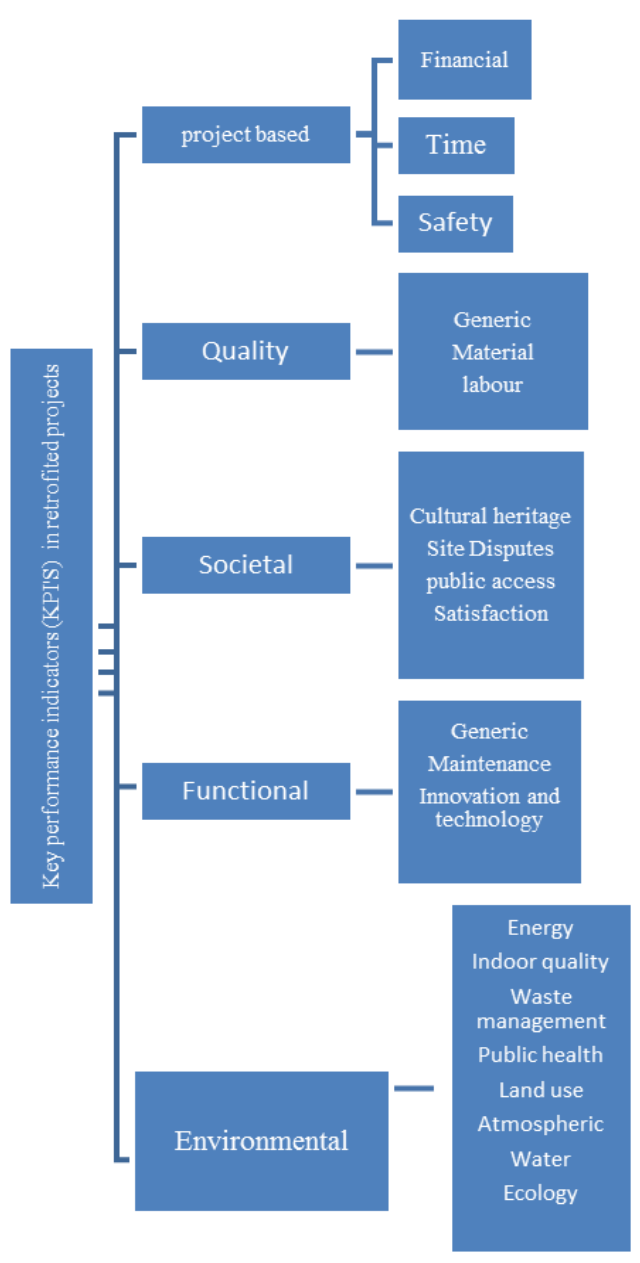

Fig. 1: Categories and sub-categories of Key Performance Indicators (KPIs) on the performance of the buildings.

\section{FUnCTIONAL KPIS}

Kometa et al. [31], opine that there would be no point in undertaking a project if it does not fulfill its intended function at the end of the day. The importance of functionality is highlighted. This indicator interacts with outlooks of project participant and can best be evaluated by the degree of conformance to all technical performance specifications [6]. Quality, technical performance and functionality are closely related and are considered important to the owner, designer, and contractor [24].

Apart from the economic and environmental social concerns taken into consideration The first objective of this set of indicators is to measure the performance of equipment (assets), at least the equipment considered part of the renovation function. through Alwaer and Clements-Croome [32], for some building renovation venture, Innovation and design process (ID), and Intelligence and controllability (IC), were acknowledged as KPIs, which come under scope of the particular research study, the adopted functional KPI was assessed on the 10-point priority scale and grounded upon the insight of the stakeholders, see table1-4. 


\section{ENVIRONMENTAL KPIS}

Another noteworthy generic group on the performance of constructing renovation that was at all times incorporated within the research studies present within literature was the environmental performance as well as the building impact. The KPIs adopted for the purpose of measuring the environmental outcome involved environmental expenses, the level of pollutants encumbering the atmosphere due to the building project, as well as the payback period. In addition, few environmental KPIs were expressed as well as computed in form of ratios and percentages, whereas others were assessed as per the opinion of stakeholders, priority is given to energy consumption, consumption of materials, waste prevention, and consumption of hazardous and environmentally harmful substances. In addition, impacts are also mentioned that concern water consumption, emissions to soil and water, noise and vibrations as well as indoor environmental conditions and conditions relating to health and safety at work.

Further, in table1-5 the environmental KPIs, have been split into 8 sub-groups based on their interest area which are:

- Generic

- Energy

- Indoor quality

- Waste management

- Public health

- Land use

- Atmospheric

- Water

- Ecology

\section{APPliCABILITY OF THE SELECTED KPIS For A RETROFITTED PROJECT ASSESSMENT}

More than 70 KPIs previously extracted from literature have been arranged according to their taxonomical nature to generic and further to their subcategories.

This Categorization is adapted to show the most frequent used KPIs and employed in projects. So it can be realized which KPIs is more important from the authors' point of view for the achievement of the level of retrofitting in a project. By looking to Table 1-1, we see the project based Indicators classified into three subcategories Financial, Time, and safety.

The financial indicator comprises of the direct costs which in turn contains the capital investment cost, lifecycle costs and profit, and the indirect costs which include those costs with side effects over the project cost like environment, materials, and financial claims. The other subcategories which are the Time and safety are also listing some important factors that would compromise the integrity of the project like for time-related KPIs, it shows management is important while the latter included KPIs related with delays.

The safety-related KPIs included KPIs deals with the safety of construction workers in the sites. Table 1-2, the search has led to identifying the quality branching into three subcategories it contains a generic form, and some writers extend to show the quality of materials as well as laborers. Table1-3, in regard to the subcategories it deals with the conservation of heritage sites and the mentioning of site disputes, such disputes due to frequent changes and specifications which have been only mentioned by Ngacho and Das [25]. Public access has also notified by Ugwu and Haupt [27] along with Feifer, [28], and you may see the indicator that refer to the perception of the stakeholders involved through the satisfaction subcategory.

Table1-4, refer to the functionality of the project renovated recently and the innovative and technological KPIs and the level of maintenance. The 27 indicators listed in the environmental Category are famous regarding the sustainability issue in retrofitted projects, with reference to table 5 the most employed subcategory is Energy, because of its consumptions and savings.

Since the construction operations is a major polluting factor of what emanates to the water, atmosphere, and land, those factors were considered by the indicators listed in the subcategories of atmospheric regarding GHG gases and waste management and reprovision of habitat in the Ecology subcategory. The developed indicators incorporate the major international sustainability metrics (economy, environment, and society), indicators should be chosen to accord with the chosen maintenance strategy [33]. Interestingly, while the literature suggests popular lists of KPIs, it misses an agreed-upon methodological approach to choosing or deriving them. Consequently, users are left to decide the applicable KPIs for their scenario. Given the lack of consensus, if measurements are to be useful, they should be simple, understandable and few in numbers, so that users can concentrate on those which are most important to them. This framework would be a good reference for designers, managers, stakeholders, and organizations which are the main objective of this study.

\begin{tabular}{|c|c|}
\hline \multicolumn{2}{|c|}{ 1. PERFORMANCE-BASED } \\
\hline Financial & 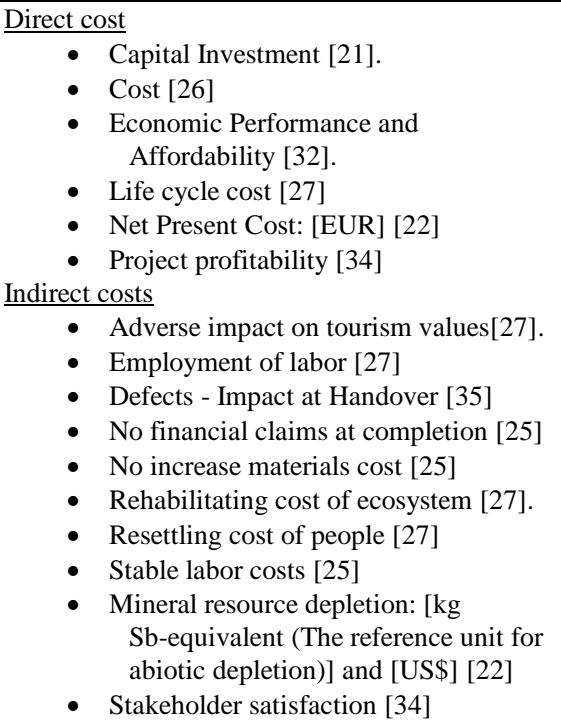 \\
\hline Time & $\begin{array}{l}\text { - A clear plan was formulated [25] } \\
\text { - Time [26]. } \\
\text { - Predictability Time-Construction [35]. } \\
\text { - Unexpected at handover there were no } \\
\text { - } \quad \text { No delays in securing funds [25] }\end{array}$ \\
\hline
\end{tabular}




\begin{tabular}{|c|c|}
\hline & $\begin{array}{l}\text { - } \\
\text { - No design changes [25] } \\
\text { - conditions [25] } \\
\text { - Timely delivery of resources[25] } \\
\text { - Predictability time_construction [35]. }\end{array}$ \\
\hline \multicolumn{2}{|r|}{$\begin{array}{l}\text { - } \text { Accidents, injuries, fatalities [27] } \\
\text { - } \quad \text { Fire safety [28] } \\
\text { - Health and safety [34]. } \\
\text { - } \text { Safety [26] } \\
\text { - } \\
\quad \begin{array}{l}\text { Safety/ Security against intruders and } \\
\text { vandalism [28] }\end{array}\end{array}$} \\
\hline \multicolumn{2}{|r|}{ 2. QUALITY } \\
\hline Generic & $\begin{array}{l}\text { - Quality [26] } \\
\text { - Quality performance [34] }\end{array}$ \\
\hline Material & $\begin{array}{l}\text { - Right material was used for the } \\
\text { construction work [25] }\end{array}$ \\
\hline Labour & $\begin{array}{l}\text { - Workers were trained on positive } \\
\text { attitudes [25]. } \\
\text { - } \quad \text { Training [35]. } \\
\end{array}$ \\
\hline \multicolumn{2}{|r|}{ 3. SOCIETAL } \\
\hline $\begin{array}{l}\text { Cultural } \\
\text { Heritage }\end{array}$ & $\begin{array}{l}\text { - Complaints from local parties/villages } \\
\text { [27] } \\
\text { - Footprint of project in archaeological } \\
\text { site [27] } \\
\text { - Extent of encroachment upon concerned } \\
\text { areas [27] } \\
\end{array}$ \\
\hline Site Disputes & $\begin{array}{l}\text { - } \\
\text { - } \\
\text { Dispute resolution meetings [25]. } \\
\text { - } 25] \text {. } \\
\text { - No serious dispute due to specifications } \\
{[25] \text {. }} \\
\text { - Staff turnover [35] }\end{array}$ \\
\hline Public Access & $\begin{array}{l}\text { - } \\
\text { Accessibility for people with specific } \\
\text { needs [28]. } \\
\text { - } \quad \text { Extent of blockage [27]. } \\
\text { - } \quad \text { Extent of congestion [27] } \\
\end{array}$ \\
\hline Satisfaction & $\begin{array}{l}\text { - Office work performance: [\% rating] } \\
\text { [29] }\end{array}$ \\
\hline \multicolumn{2}{|r|}{ 4. FUNCTIONAL } \\
\hline Generic & $\begin{array}{l}\text { - Functionality [26] } \\
\text { - Functionality, Usability, and aesthetic } \\
\text { aspects [32]. }\end{array}$ \\
\hline $\begin{array}{l}\text { Maintenance } \\
\text { requirements }\end{array}$ & - Maintenance requirement [28] \\
\hline $\begin{array}{l}\text { Innovation and } \\
\text { technology }\end{array}$ & $\begin{array}{ll} & \text { Innovation and design process [32] } \\
\text { - Intelligence and controllability [32] }\end{array}$ \\
\hline \multicolumn{2}{|r|}{ 5. ENVIRONMENTAL } \\
\hline Generic & $\begin{array}{l}\text { - } \\
\text { - } \\
\text { Utilized environmental friendliness [26] } \\
\text { technology [25]. } \\
\text { - Impact on the environment } \\
\text { (construction process performance), } \\
\text { [36] }\end{array}$ \\
\hline Energy & $\begin{array}{l}\text { - } \\
\text { Energy consumption and resources } \\
\text { saving[34] } \\
\text { - } \quad \text { Energy management[34]. Energy } \\
\quad \text { Payback Time: [yrs] [37] } \\
\text { - } \quad \text { Peak Energy Demand Reduction for } \\
\quad \text { building operations [32] } \\
\text { - } \quad \text { Renewable primary energy [28] } \\
\text { - } \quad \text { Site orientation to maximize passive } \\
\quad \text { solar potential [32]. }\end{array}$ \\
\hline Indoor quality & $\begin{array}{l}\text { - } \quad \text { Humidity [28]. } \\
\text { - Indoor air quality [28]. } \\
\text { - Indoor Environmental Quality-Health } \\
\text { and Wellbeing [32]. Overheating risk: } \\
\quad \text { [\% rating] [29] }\end{array}$ \\
\hline
\end{tabular}

\begin{tabular}{|c|c|}
\hline & $\begin{array}{l}\text { - } \quad \text { Ventilation design- during } \\
\quad \text { construction [27] } \\
\text { - } \quad \text { Ventilation design-service stage [27]. } \\
\text { - } \quad \text { Acoustic performance [28] }\end{array}$ \\
\hline $\begin{array}{l}\text { Waste } \\
\text { management }\end{array}$ & $\begin{array}{l}\text { - } \\
\text { - } \\
\text { - Increased solid waste [25] } \\
\text { Materials used Durability and Waste } \\
\text { [32]. }\end{array}$ \\
\hline Public health & - Public health[27]. \\
\hline Land use & - Connectivity with hinterland [27]. \\
\hline atomospheric & $\begin{array}{l}\text { - } \text { GHG emissions: [kg CO2-equivalent/kg } \\
\text { emissions] [22] } \\
\text { - Global warming potential }[28,38] \\
\end{array}$ \\
\hline Water & $\begin{array}{l}\text { - } \\
\text { Acidification of land and water } \\
\text { resources [28] } \\
\text { - } \quad \text { Freshwater resources [28] } \\
\text { - } \quad \text { Quality of water use in buildings [28]. } \\
\text { - Water reuse [27] }\end{array}$ \\
\hline Ecology & - Reprovision of habitat [27] \\
\hline
\end{tabular}

\section{CONCLUSION}

A vast amount of performance management of construction projects has emerged but not too many on retrofitting projects. A need is to have a comprehensive desktop literature review on the efforts of international approaches to benchmark the retrofitting projects from a number of key performance indicators(KPIs). Five different perspectives as generic categories were adopted, related to project-based, quality, societal, and environmental aspects, and also many subcategories for each. The analysis of the work showed there was not a common consensus about the classification or a standardized methodology for the categorization. This review summed the what is the trending KPIs used in retrofitting projects in order to assess the level of sustainability. Most authors are concentrating on the development of the sustainability index of buildings. The next steps are the building of standardized basis for the sustainability performance for national and international usage.

\section{REFERENCES}

[1] R. Bon and R. Pietroforte, "New construction versus maintenance and repair construction technology in the US since World War II," Construction Management and Economics, vol. 11, pp. 151-162, 1993. https://doi.org/10.1080/01446199300000008

[2] L. Kanapeckiene, A. Kaklauskas, E. K. Zavadskas, and S. Raslanas, "Method and system for multi-attribute market value assessment in analysis of construction and retrofit projects," Expert systems with applications, vol. 38, pp. 14196-14207, 2011. https://doi.org/10.1016/j.eswa.2011.04.232

[3] B. Zhu and D. M. Frangopol, "Reliability, redundancy and risk as performance indicators of structural systems during their life-cycle," Engineering Structures, vol. 41, pp. 34-49, 2012. https://doi.org/10.1016/j.engstruct.2012.03.029

[4] D. Ahadzie, D. Proverbs, and P. Olomolaiye, "Critical success criteria for mass house building projects in developing countries," International Journal of Project Management, vol. 26, pp. 675-687, 2008. https://doi.org/10.1016/j.ijproman.2007.09.006

[5] R. Atkinson, "Project management: cost, time and quality, two best guesses and a phenomenon, its time to accept other success criteria," International journal of project management, vol. 17, pp. 337-342, 1999 https://doi.org/10.1016/S0263-7863(98)00069-6. 
[6] A. P. Chan, D. Scott, and E. W. Lam, "Framework of success criteria for design/build projects," Journal of management in engineering, vol. 18, pp. 120-128, 2002. https://doi.org/10.1061/(ASCE)0742-597X(2002)18:3(120)

[7] R. Salleh, "Critical success factors of project management for Brunei construction projects: improving project performance," Queensland University of Technology, 2009.

[8] T. Beck, "Evaluating humanitarian action using the OECD-DAC criteria," Londres, Overseas Development Institute, 2006.

[9] T. Chianca, "The OECD/DAC criteria for international development evaluations: An assessment and ideas for improvement," Journal of Multidisciplinary Evaluation, vol. 5, pp. 41-51, 2008.

[10] L. A. Ika, A. Diallo, and D. Thuillier, "Critical success factors for World Bank projects: An empirical investigation," International journal of project management, vol. 30, pp. 105-116, 2012. https://doi.org/10.1016/j.ijproman.2011.03.005

[11] D. Myers, Construction economics: A new approach: Taylor \& Francis, 2016.

[12] M. Kušar, M. Š. Kovač, and J. Šelih, "Selection of Efficient Retrofit Scenarios for Public Buildings," Procedia Engineering, vol. 57, pp. 651-656, 2013. https://doi.org/10.1016/j.proeng.2013.04.082

[13] B. Chanter and P. Swallow, "Maintenance Organisations," Building Maintenance Management, Second Edition, pp. 55-90, 1996.

[14] A. Griffith and J. Headley, "Using a weighted score model as an aid to selecting procurement methods for small building works," Construction Management \& Economics, vol. 15, pp. 341-348, 1997. https://doi.org/10.1080/014461997372890

[15] D. Sherwin, "A review of overall models for maintenance management," Journal of quality in maintenance engineering, vol. 6, pp. 138-164, 2000 https://doi.org/10.1108/13552510010341171

[16] C.-H. Ko and M.-Y. Cheng, "Dynamic prediction of project success using artificial intelligence," Journal of construction engineering and management, vol. 133, pp. 316-324, 2007. https://doi.org/10.1061/(ASCE)0733-9364(2007)133:4(316)

[17] R. Takim and A. Akintoye, "Performance indicators for successful construction project performance," in 18th Annual ARCOM Conference, 2002, pp. 545-555.

[18] D. Allen, "What is building maintenance?," Facilities, vol. 11, pp. 7-12, 1993. https://doi.org/10.1108/EUM0000000002230

[19] C. C. Keung and L.-y. Shen, "Measuring the networking performance for contractors in practicing construction management," Journal of Management in Engineering, vol. 29, pp. 400-406, 2012. https://doi.org/10.1061/(ASCE)ME.1943-5479.0000156

[20] B. Ozorhon, D. Arditi, I. Dikmen, and M. T. Birgonul, "Toward a multidimensional performance measure for international joint ventures in construction," Journal of construction engineering and management, vol. 137, pp. 403-411, 2010. https://doi.org/10.1061/(ASCE)CO.1943-7862.0000314

[21] N. P. Dunphy, J. Little, and R. van der Krogt, "Model for retrofit configuration selection using multiple decision diagrams," in Proceedings of the 2012 Building Simulation and Optimization Conference. Loughborough, UK: Loughborough University, 2012, pp. 309-316.

[22] L. Dijkstra, "An environmental and economic impact comparison of renovation concepts for Dutch residential buildings," 2013.

[23] O. Ugwu and T. Haupt, "Key performance indicators and assessment methods for infrastructure sustainability - a South African construction industry perspective," Building and Environment, vol. 42, pp. 665-680, 2007. https://doi.org/10.1016/j.buildenv.2005.10.018

[24] A. P. Chan and A. P. Chan, "Key performance indicators for measuring construction success," Benchmarking: an international journal, vol. 11, pp. 203-221, 2004.

[25] C. Ngacho and D. Das, "A performance evaluation framework of development projects: An empirical study of Constituency Development Fund (CDF) construction projects in Kenya," International Journal of Project Management, vol. 32, pp. 492-507, 2014. https://doi.org/10.1016/j.ijproman.2013.07.005
[26] M. R. Yahya and M. N. Ibrahim, "Building maintenance achievement in high rise commercial building: a study in Klang Valley, Malaysia," 2012.

[27] O. Ugwu and T. Haupt, "Key performance indicators for infrastructure sustainability-a comparative study between Hong Kong and South Africa," Journal of Engineering, Design and Technology, vol. 3, pp. 30-43, 2005. https://doi.org/10.1108/17260530510815321

[28] L. Feifer, "Sustainability indicators in buildings. Identifying key performance indicators," Peer-reviewed and published in PLEA, 2011.

[29] P. De Wilde and W. Tian, "Predicting the performance of an office under climate change: A study of metrics, sensitivity and zonal resolution," Energy and Buildings, vol. 42, pp. 1674-1684, 2010. https://doi.org/10.1016/j.enbuild.2010.04.011

[30] J. Case, "Using measurement to boost your unit's performance," Harvard Management Update, vol. 3, pp. 1-4, 1998.

[31] S. T. Kometa, P. O. Olomolaiye, and F. C. Harris, "An evaluation of clients' needs and responsibilities in the construction process," Engineering, construction and Architectural management, vol. 2, pp. 57-76, 1995. https://doi.org/10.1108/eb021003

[32] H. Alwaer and D. Clements-Croome, "Key performance indicators (KPIs) and priority setting in using the multi-attribute approach for assessing sustainable intelligent buildings," Building and Environment, vol. 45, pp. 799-807, 2010 https://doi.org/10.1016/j.buildenv.2009.08.019

[33] U. Kumar and H. Ellingson, "Development and implementation of maintenance performance indicators for the Norweigan oil and gas industry," in Development and implementation of maintenance performance indicators for the Norweigan oil and gas industry: 07/03/2000-10/03/2000, 2000, pp. 221-228.

[34] P. Peng Xu, E. H. Chan, and Q. K. Qian, "Key performance indicators (KPI) for the sustainability of building energy efficiency retrofit (BEER) in hotel buildings in China," Facilities, vol. 30, pp. 432-448, 2012. https://doi.org/10.1108/02632771211235242

[35] C. Excellence, glenigan, "UK Industry Performance Report 2014-Based on the UK Construction Industry Key Performance Indicators," 2014.

[36] C. Excellence, "UK Industry Performance Report 2011-Based on UK Cons truction Industry Performance Indicators," ed: Published by Constructing Excellence, London, UK, 2011.

[37] F. Ardente, M. Beccali, M. Cellura, and M. Mistretta, "Energy and environmental benefits in public buildings as a result of retrofit actions," Renewable and Sustainable Energy Reviews, vol. 15, pp. 460-470, 2011. https://doi.org/10.1016/j.rser.2010.09.022

[38] K. Hansen and E. H. Petersen, "Environmental assessment of renovation projects," Proc. Sustain. Build, vol. 2012, 2002. 